Article

\title{
Antioxidant, Analgesic, Anti-Inflammatory, and Hepatoprotective Effects of the Ethanol Extract of Mahonia oiwakensis Stem
}

\section{Jung Chao ${ }^{1}$, Jiunn-Wang Liao ${ }^{2}$, Wen-Huang Peng ${ }^{3}$, Meng-Shiou Lee ${ }^{3}$, Li-Heng Pao ${ }^{4,5}$ and Hao-Yuan Cheng ${ }^{6, *}$}

1 Department and Institute of Pharmacology, National Yang-Ming University, Taipei 112, Taiwan; E-Mail: rich720925@yahoo.com.tw

2 Graduate Institute of Veterinary Pathobiology, National Chung Hsing University, Taichung 402, Taiwan; E-Mail: jwliao@dragon.nchu.edu.tw

3 School of Chinese Pharmaceutical Sciences and Chinese Medicine Resources, College of Pharmacy, China Medical University, Taichung 404, Taiwan;

E-Mails: whpeng@mail.cmu.edu.tw (W.-H.P.); leemengshiou@mail.cmu.edu.tw (M.-S.L.)

4 Department of biotechnology, Trans World University, Yunlin 640, Taiwan;

E-Mail:paolh@ndmctsgh.edu.tw

5 School of Pharmacy, National Defense Medical Center, Taipei 114, Taiwan

6 Department of Nursing, Chung-Jen College of Nursing, Health Sciences and Management, Chiayi 600, Taiwan

* Author to whom correspondence should be addressed; E-Mail: m098026@cjc.edu.tw; Tel.: +886-5-2658880 (ext. 227); Fax: +886-5-2658913.

Received: 17 November 2012; in revised form: 7 January 2013 / Accepted: 10 January 2013 / Published: 30 January 2013

\begin{abstract}
The aim of this study was to evaluate pharmacological properties of ethanol extracted from Mahonia oiwakensis Hayata stems $\left(\mathrm{MOS}_{\mathrm{EtOH}}\right)$. The pharmacological properties included antioxidant, analgesic, anti-inflammatory and hepatoprotective effects. The protoberberine alkaloid content of the $\mathrm{MOS}_{\mathrm{EtOH}}$ was analyzed by high-performance liquid chromatography (HPLC). The results revealed that three alkaloids, berberine, palmatine and jatrorrhizine, could be identified. Moreover, the $\mathrm{MOS}_{\mathrm{EtOH}}$ exhibited antioxidative activity using the DPPH assay $\left(\mathrm{IC}_{50}, 0.743 \mathrm{mg} / \mathrm{mL}\right)$. The DPPH radical scavenging activity of $\mathrm{MOS}_{\mathrm{EtOH}}$ was five times higher that that of vitamin $\mathrm{C}$. MOS $\mathrm{M}_{\mathrm{EtOH}}$ was also found to inhibit pain induced by acetic acid, formalin, and carrageenan inflammation. Treatment with $\mathrm{MOS}_{\mathrm{EtOH}}(100$ and $500 \mathrm{mg} / \mathrm{kg})$ or silymarin $(200 \mathrm{mg} / \mathrm{kg})$ decreased the
\end{abstract}


serum alanine aminotransferase (ALT) and aspartate aminotransferase (AST) levels compared with the $\mathrm{CCl}_{4}$-treated group. Histological evaluation showed that $\mathrm{MOS}_{\mathrm{EtOH}}$ reduced the degree of liver injury, including vacuolization, inflammation and necrosis of hepatocytes. The anti-inflammatory and hepatoprotective effect of $\mathrm{MOS}_{\mathrm{EtOH}}$ were found to be related to the modulation of antioxidant enzyme activity in the liver and decreases in malondialdehyde (MDA) level and nitric oxide (NO) contents. Our findings suggest that $\mathrm{MOS}_{\mathrm{EtOH}}$ has analgesic, anti-inflammatory and hepatoprotective effects. These effects support the use of $\mathrm{MOS}_{\mathrm{EtOH}}$ for relieving pain and inflammation in folk medicine.

Keywords: Mahonia oiwakensis Hayata; high-performance liquid chromatography; hepatoprotective effect; malondialdehyde

\section{Introduction}

Liver disorders are commonly caused by either toxic chemicals, drugs, or pathogen infection [1], and are considered extremely serious health problems in modern society. During chemical-induced liver injury, $\mathrm{CCl}_{4}$ metabolism begins with formation of the trichloromethyl free radical, $\mathrm{CCl}_{3}$, via the mixed function cytochrome $\mathrm{P} 450$ oxygenase system of the endoplasmic reticulum $[2,3] . \mathrm{CCl}_{3} \cdot \mathrm{can}$ also react with oxygen to form the trichloromethylperoxyl radical, $\mathrm{CCl}_{3} \mathrm{OO}$, which is a highly reactive species [3]. Thus, $\mathrm{CCl}_{3} \mathrm{OO} \cdot$ is more likely than $\mathrm{CCl}_{3} \cdot$ to abstract hydrogen from polyunsaturated fatty acids (PUFA), which leads to lipid peroxidation [4] and protein oxidation; these effects then cause hepatocellular membrane damage [5]. Additionally, $\mathrm{CCl}_{4}$-induced toxicity may stimulate endogenous reactive oxygen and nitrogen species production that seems to play an important role in the pathogenesis of hepatotoxicity. This process is followed by the release of inflammatory mediators from activated hepatic macrophages that are believed to promote $\mathrm{CCl}_{4}$-induced hepatic injury [2].

Many species of the Mahonia genus are considered to be medicinal plants [6-8]. Three species of Mahonia (Berberidaceae) grow in Taiwan [9]. The herbs Mahonia japonica and Mahonia oiwakensis are both native to Taiwan. All species of this genus in Taiwan are considered medicinal plants. Mahonia oiwakensis Hayata (MO), a popular folk medicine in Taiwan, is traditionally used by herbalists and Chinese doctors as a substitute for Phellodendri cortex, which is the bark of Phellodendron amurense or Phellodendron chinese (Rutaceae). The latter two preparations are known traditionally as antipyretic and analgesic drugs and also used for abdominal pain and diarrhea, inflammatory disorders (e.g., rheumarthritis), gastrointestinal disorders (e.g., dysentery and acute gastroenteritis), and liver disease (e.g., hepatitis) [9]. MO has been demonstrated to exhibit anti-tumor and anti-inflammatory activity $[10,11]$. Medical alcohol extracts of MO stems $\left(\mathrm{MOS}_{\mathrm{EtOH}}\right)$ are used to treat the common cold and enterogastritis in Taiwan $[12,13]$. However, scientific data on the chemical structure of the active ingredients and the hepatoprotective activity of $\mathrm{MOS}_{\mathrm{EtOH}}$ are lacking.

This study was conducted to investigate the protoberberine alkaloid content of $\mathrm{MOS}_{\mathrm{EtOH}}$ and its hepatoprotective activity. Protoberberine alkaloids are the dominant components found in Berberis, Mahonia and Coptis plant material [14]. Berberine and palmatine are the most medically significant protoberberine alkaloids. Therefore, the chemical components of $\mathrm{MOS}_{\mathrm{EtOH}}$ was identified by high 
performance liquid chromatography (HPLC). Next, this study used in vivo and in vitro models to evaluate the antioxidative effect of $\mathrm{MOS}_{\mathrm{EtOH}}$ and elucidate its possible hepatoprotective effects in rats. To examine the possible antioxidative activity of $\mathrm{MOS}_{\mathrm{EtOH}}$, the 1,1-diphenyl-2-picrylhydrazyl (DPPH) radical scavenging assay was employed. Finally, the hepatoprotective effect of $\mathrm{MOS}_{\mathrm{EtOH}}$ was determined using a $\mathrm{CCl}_{4}$-induced acute liver injury model. Silymarin, an effective therapic agent when there is $\mathrm{CCl}_{4}$-induced acute liver injury, was used as the therapeutic control.

\section{Results and Discussion}

\subsection{Chromatographic Analysis of $M O S_{E t O H}$}

The major bioactive components in Mahonia plants are alkaloids [15]. The HPLC chromatogram showed that jatrorrhizine, berberine, and palmatine were the major components among organic molecules found in $\mathrm{MOS}_{\mathrm{EtOH}}$, which had a maximum absorbance at $350 \mathrm{~nm}$ (Figure 1). This analytical result also indicated that the various different alkaloids present in $\mathrm{MOS}_{\mathrm{EtOH}}$ were found at the following levels: berberine $135.84 \pm 0.19 \mathrm{mg} / \mathrm{g}$ extract, palmatine $85.60 \pm 0.03 \mathrm{mg} / \mathrm{g}$ extract, and jatrorrhizine $72.09 \pm 0.46 \mathrm{mg} / \mathrm{g}$ extract.

Figure 1. The HPLC chromatographic profile of $\mathrm{MOS}_{\mathrm{EtOH}} \cdot \lambda=350 \mathrm{~nm}$ showing the detection of jatrorrhizine, berberine and palmatine.

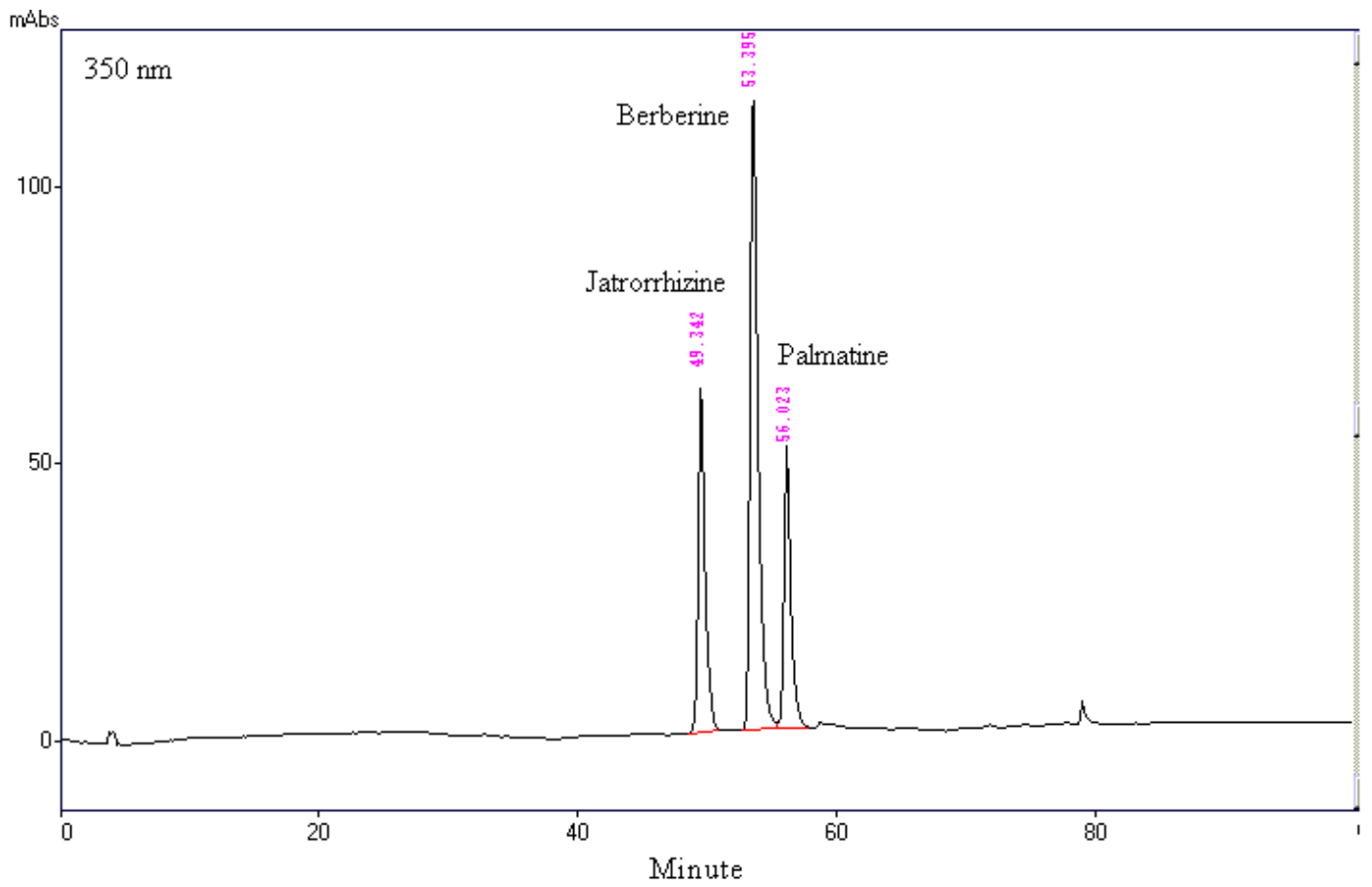

\subsection{The DPPH Radical Scavenging Activity of $M O S_{E t O H}$}

Evaluation of the antioxidative activity of $\mathrm{MOS}_{\mathrm{EtOH}}$ was carried out using a DPPH radical-producing system. The $\mathrm{IC}_{50}$ of $\mathrm{MOS}_{\mathrm{EtOH}}$ was $0.743 \mathrm{mg} / \mathrm{mL}$. The $\mathrm{IC}_{50}$ of ascorbic acid (Vit. C) and 2,6-Di-tert-butyl-4-methylphenol (BHT) using the same system were 0.134 and $0.085 \mathrm{mg} / \mathrm{mL}$ (Table 1). 
Table 1. The $\mathrm{IC}_{50}$ values of $\mathrm{MOS}_{\mathrm{EtOH}}$ in $\mathrm{DPPH}$ radical scavenging activity.

\begin{tabular}{cc}
\hline Substance & DPPH radical scavenging activity $\left(\mathrm{IC}_{\mathbf{5 0}}, \mathbf{m g} / \mathbf{m L}\right)$ \\
\hline MOS $_{\mathrm{EtOH}}$ & $0.743 \pm 0.023$ \\
Vit. C & $0.134 \pm 0.015$ \\
BHT & $0.085 \pm 0.002$ \\
\hline
\end{tabular}

$\mathrm{MOS}_{\mathrm{EtOH}}$ : ethanol extracted from MO stems; DPPH: 1,1-diphenyl-2-picrylhydrazyl; Vit. C: ascorbic acid; BHT: 2,6-Di-tert-butyl-4-methylphenol. Values are mean $\pm \mathrm{SE}(n=3)$.

\subsection{Toxicity Study}

The acute toxicity of $\mathrm{MOS}_{\mathrm{EtOH}}$ was evaluated using mice and doses up to $5000 \mathrm{mg} / \mathrm{kg}$ (p.o.) body weight administered for $72 \mathrm{~h}$. $\mathrm{MOS}_{\mathrm{EtOH}}$ did not cause any behavioral changes and no deaths occurred (data not shown). Thus the oral $\mathrm{LD}_{50}$ value of $\mathrm{MOS}_{\mathrm{EtOH}}$ was greater than $5000 \mathrm{mg} / \mathrm{kg}$ body weight in mice and it can be considered to be practically a non-toxic substance. No toxicity symptoms were recorded. The lack of lethality means that the oral route of $\mathrm{MOS}_{\mathrm{EtOH}}$ in mice cannot be determined to $5000 \mathrm{mg} / \mathrm{kg}$.

\subsection{Analgesic and Anti-Inflammatory Activity of $M O S_{E t O H}$}

MOS $_{\mathrm{EtOH}}$ was used to decrease the acetic acid-induced writhing responses in mice, which is an indication of the extract's analgesic activity (Figure 2). Treatment with $\operatorname{MOS}_{\mathrm{EtOH}}(100$ and $500 \mathrm{mg} / \mathrm{kg}$ ) or indomethacin $(10 \mathrm{mg} / \mathrm{kg})$ resulted in an inhibition of the writhing number compared to the control. Furthermore, there are no significant inhibitions during the early phase (Figure $3 \mathrm{~A}$ ). $\mathrm{MOS}_{\mathrm{EtOH}}$ $(500 \mathrm{mg} / \mathrm{kg})$ decreased the licking time during the late phase of the formalin-induced pain test (Figure 3B, $p<0.05$ ).

Figure 2. Analgesic effect of $\mathrm{MOS}_{\mathrm{EtOH}}$ on acetic acid-induced writhing response in mice. Indomethacin (Indo $10 \mathrm{mg} / \mathrm{kg}$ ) was use as a therapeutic control. The number of muscular contractions was evaluated as described in Section 2. Treatment of $\operatorname{MOS}_{\mathrm{EtOH}}(20,100$ and $500 \mathrm{mg} / \mathrm{kg})$ and Indo $(10 \mathrm{mg} / \mathrm{kg})$ showed that there was an inhibition of writhing number compared to the control. Each value represents as mean $\pm \operatorname{SEM}(n=10)$. ${ }^{*} p<0.05$ as compared with the acetic acid-treated only group.

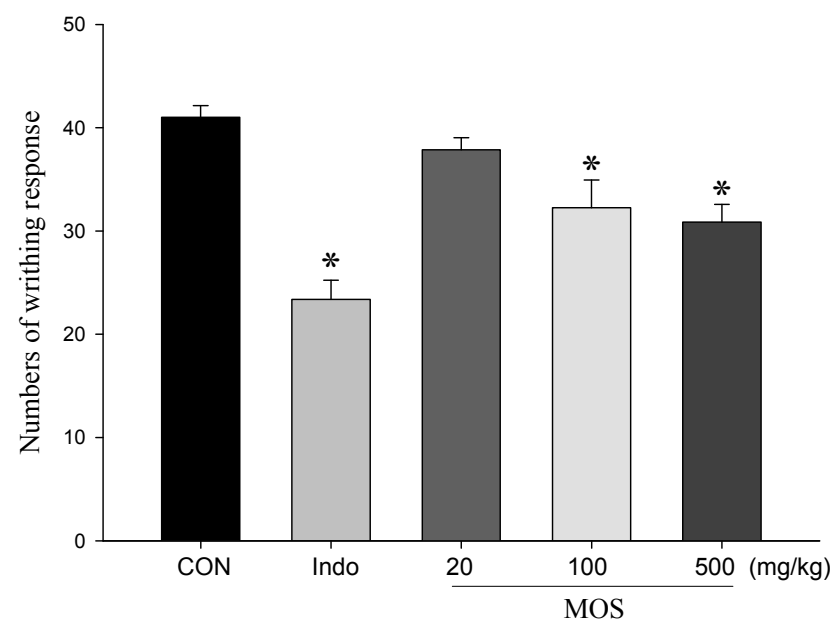


Figure 3. Effect of $\mathrm{MOS}_{\mathrm{EtOH}}$ on (A) the early phase and (B) the late phase of the formalin test in mice. The index of pain (early phase and late phase) was evaluated as described in Section 2. $\operatorname{MOS}_{\mathrm{EtOH}}(500 \mathrm{mg} / \mathrm{kg})$ decreased the licking time during the late phase of formalin-induced pain test. Each value represents as mean $\pm \operatorname{SEM}(n=10) .{ }^{*} p<0.05$ as compared with the formalin-treated only group.
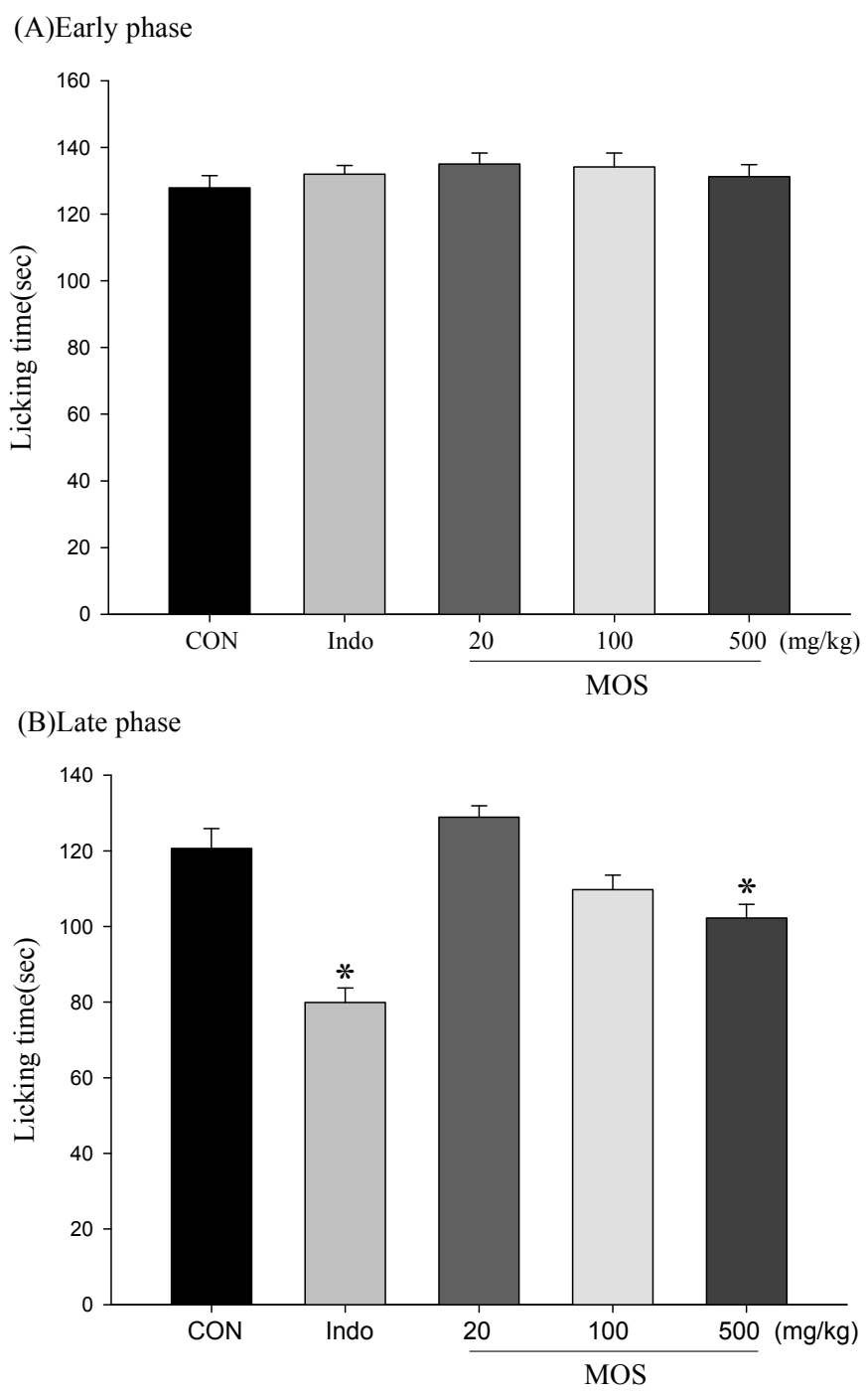

\section{5. $\mathrm{MOS}_{\text {EtOH-Inhibited Carrageenan-Induced Edema and Inflammation in Mice Paw Tissue }}$}

Carrageenan-induced mice paw edema is a biphasic process. During early hyperemia, which occurs 0-2 $\mathrm{h}$ after the carrageenan injection, there is a release of histamine, serotonin, and bradykinin that results in increased vascular permeability. The inflammatory edema reached its maximum level during the second hour and then begins to decline. In our study, paw edema was increased and reached a maximum at $2 \mathrm{~h}$ after carrageenan injection. Treatment with $\operatorname{MOS}_{\mathrm{EtOH}}(20,100$ and $500 \mathrm{mg} / \mathrm{kg}$ ) significantly reduced paw edema formation $(p<0.001)$ as shown in Figure 4 . The inhibition rate at $2 \mathrm{~h}$ was $45 \%$ to $55 \%$ after treatment with $\operatorname{MOS}_{\mathrm{EtOH}}(20,100$ and $500 \mathrm{mg} / \mathrm{kg})$ or indomethacin. 
Figure 4. Inhibitory effects of $\mathrm{MOS}_{\mathrm{EtOH}}$ on carrageenan-induced mice paw inflammation. Treatment with $\mathrm{MOS}_{\mathrm{EtOH}}(20,100$ and $500 \mathrm{mg} / \mathrm{kg}$ ) significantly reduced paw volume. Delta volume $(\Delta \mathrm{V})$ represents the degree of swelling of carrageenan-treated paw. Each value represents the mean $\pm \operatorname{SEM}(n=10) .{ }^{*} p<0.05 * * p<0.01, * * * p<0.001$ as compared with the carrageenan-treated only group.

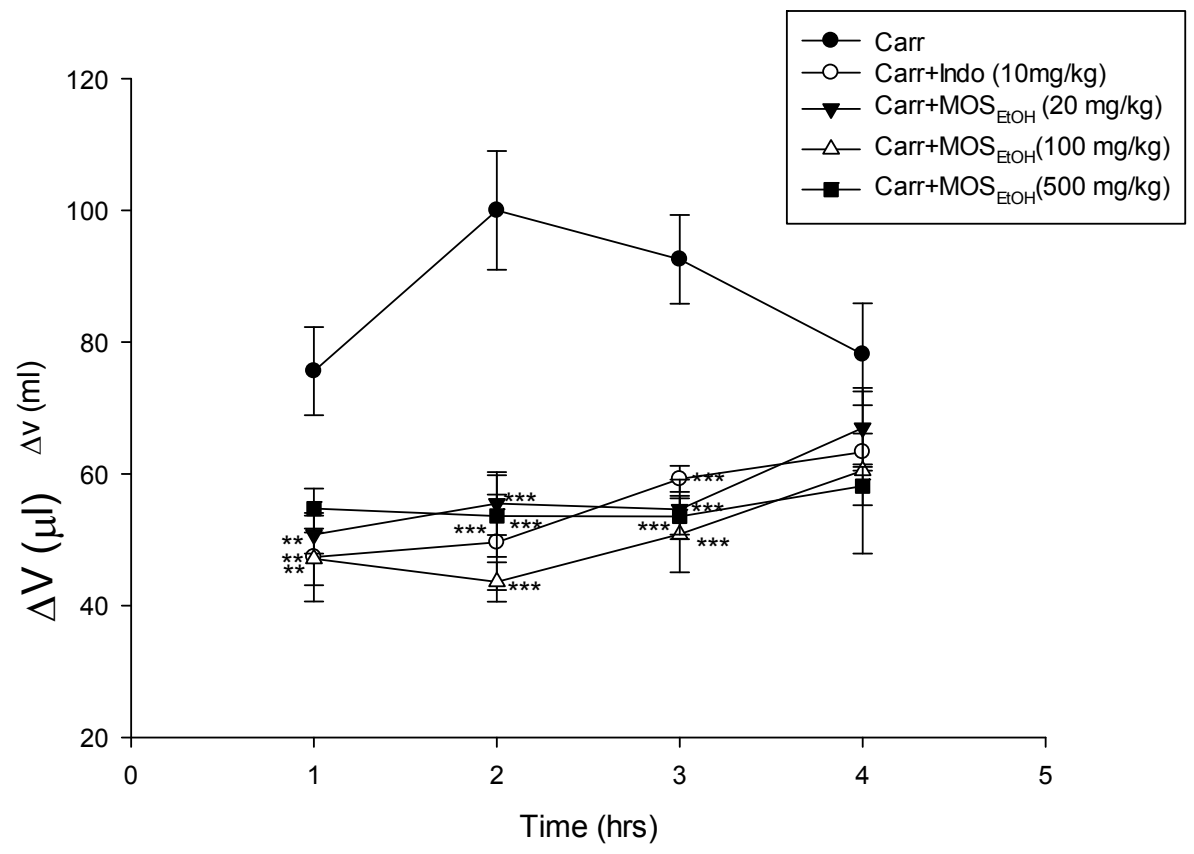

Figure 5. Effect of $\mathrm{MOS}_{\mathrm{EtOH}}$ of serum AST and ALT in rats after intraperitoneally treated with $\mathrm{CCl}_{4}$. Values are mean $\pm \mathrm{SE}(n=6)$. ${ }^{\#}$ Significantly different from the control group $\left({ }^{\# \# \#} p<0.001\right)$; * Significantly different from the $\mathrm{CCl}_{4}$ group $(* p<0.05$, ** $p<0.01$, $* * * p<0.001)$.

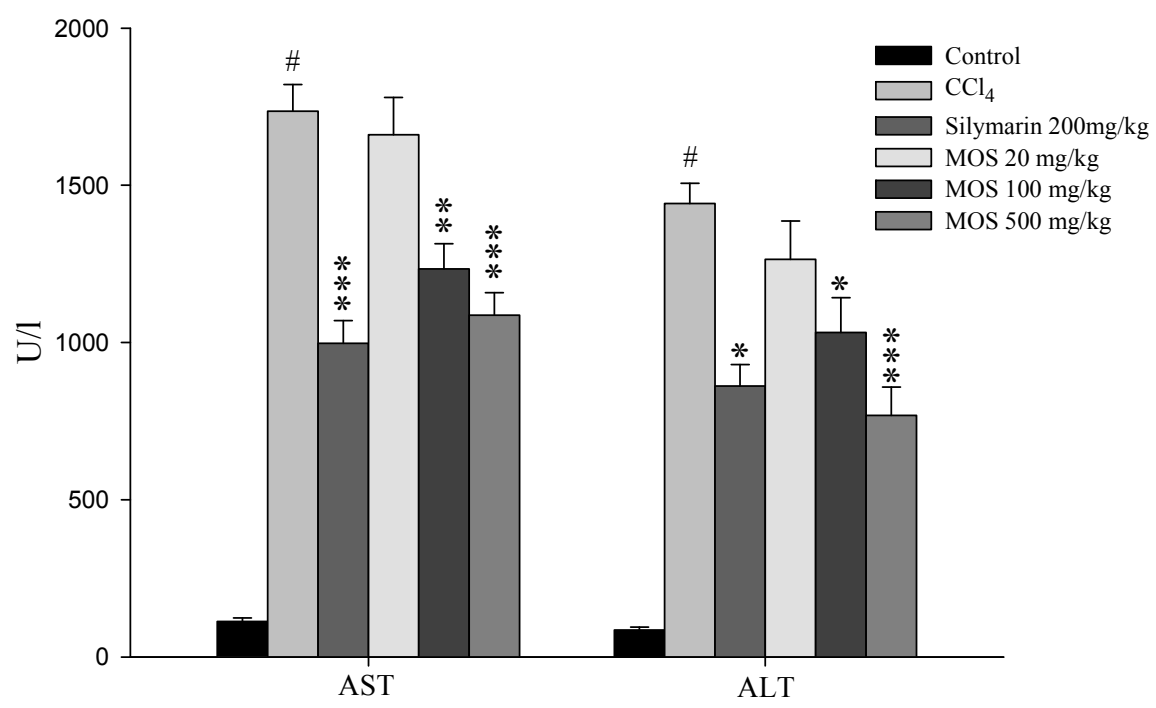

\subsection{Hepatoprotective Effect of $M O S_{E t O H}$}

Both AST and ALT are cytosolic enzymes present in hepatocytes and are released into circulation once cellular damage occurs. Figure 5 shows that the changes in serum AST and ALT activities for 
various group of animals. The serum levels of ALT and AST in untreated control group of animals were $112.5 \pm 11.2 \mathrm{U} / \mathrm{L}$ and $85.7 \pm 9.3 \mathrm{U} / \mathrm{L}$, respectively. After $\mathrm{CCl}_{4}$ treatment, the serum ALT and AST activities increased by approximately 16.9 and 18.4-fold compared to the control group. In contrast, the serum AST and ALT levels showed a significantly lower increase when the rats were treated with $\mathrm{MOS}_{\mathrm{EtOH}}$ compared to the $\mathrm{CCl}_{4}$ alone group of rats. Similar results were obtained when the rats were treated with silymarin, a known hepatoprotective chemical.

Figure 6. Effect of $\mathrm{MOS}_{\mathrm{EtOH}}$ on $\mathrm{CCl}_{4}$-induced liver injury in rats. (A) The normal architecture of the liver of the control group; (B) The livers of animals treated with $50 \%$ $\mathrm{CCl}_{4}(1 \mathrm{~mL} \mathrm{~kg} / \mathrm{bw})$ showed marked cell necrosis (big arrow), vacuolization (small arrow) and inflammation with numerous neutrophilic infiltrations (small arrowhead). Fewer injured hepatocytes were found after treatment with sylimarin $(200 \mathrm{mg} / \mathrm{kg}) ;(\mathbf{C})$ treatment with $\operatorname{MOS}_{\mathrm{EtOH}}(20,100$ and $500 \mathrm{mg} / \mathrm{kg}$; D, E, and F groups, respectively). Hematoxylin and $\operatorname{eosin}(\mathrm{H}$ and $\mathrm{E})$ stain, $100 \times$ magnification.
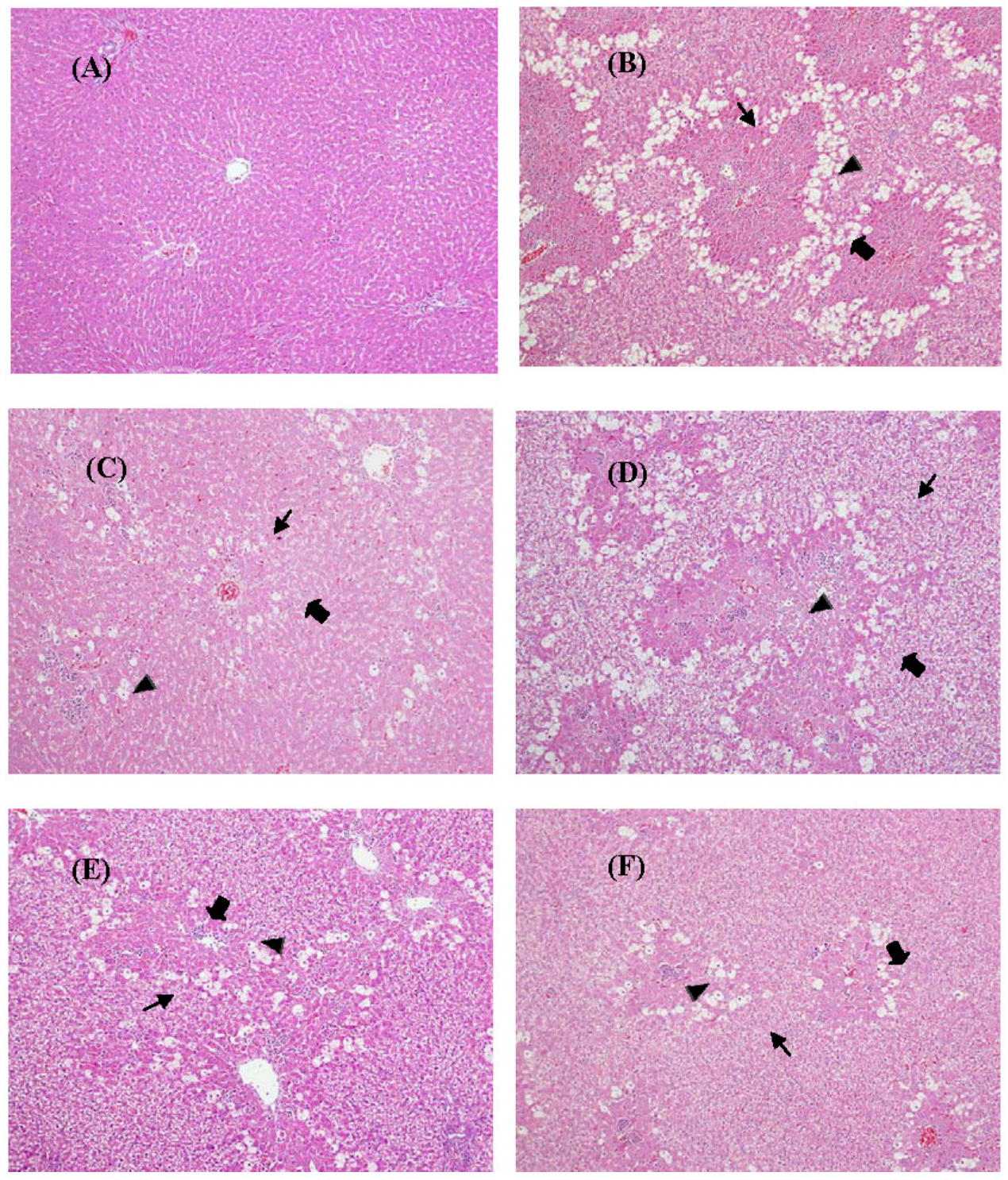


\subsection{Histological Analysis}

As compared with the control group of rats (Figure 6A), hepatic cell injury, including vacuolization, inflammation with neutrophilic infiltration and extended necrotic areas adjacent to portal triads, were present in the $\mathrm{CCl}_{4}$-treated group (Figure 6B). Treatment with silymarin significantly inhibited $\mathrm{CCl}_{4}$-induced hepatic injury (Figure 6C). The histopathological morphology of the $\mathrm{MOS}_{\mathrm{EtOH}}$ treated groups $(20,100$, and $500 \mathrm{mg} / \mathrm{kg})$ are shown in Figure $6 \mathrm{C}-\mathrm{E}$. $\mathrm{CCl}_{4}$-induced acute liver damage in rats was attenuated after treatment with 100 and $500 \mathrm{mg} / \mathrm{kg}$ of $\mathrm{MOS}_{\mathrm{EtOH}}$. Table 2 summarizes the data on the degree of liver damage induced by $\mathrm{CCl}_{4}$ for each group. The histoscores for vacuolization, inflammation and cellular necrosis of the livers were significantly higher after $\mathrm{CCl}_{4}$ treatment. In contrast, pretreatment with $\mathrm{MOS}_{\mathrm{EtOH}}(500 \mathrm{mg} / \mathrm{kg})$ and silymarin significantly reduced the injury histoscores of the livers from these groups.

Table 2. Histoscores of livers treated with either silymarin or $\mathrm{MOS}_{\mathrm{EtOH}}$ using the rat $\mathrm{CCl}_{4}$-induced hepatotoxicity assay.

\begin{tabular}{|c|c|c|c|c|c|c|}
\hline \multirow{3}{*}{ Histo-grade } & \multicolumn{6}{|c|}{ Group } \\
\hline & \multirow{2}{*}{ Control } & \multirow{2}{*}{$\mathrm{CCl}_{4}$} & \multirow{2}{*}{$\begin{array}{l}\text { Silymarin } \\
200 \mathrm{mg} / \mathrm{kg}\end{array}$} & \multicolumn{3}{|c|}{$\operatorname{MOS}_{\text {EtOH }}(\mathrm{mg} / \mathrm{kg})$} \\
\hline & & & & 20 & 100 & 500 \\
\hline Vacuolization & 0 & $3.2 \pm 0.2^{\# \#}$ & $1.7 \pm 0.2^{* *}$ & $2.8 \pm 0.3$ & $2.5 \pm 0.2$ & $2.2 \pm 0.2 * *$ \\
\hline Inflammation & 0 & $2.7 \pm 0.2^{\# \#}$ & $1.7 \pm 0.2^{*}$ & $2.3 \pm 0.2$ & $2.0 \pm 0.3$ & $1.5 \pm 0.2 *$ \\
\hline Cellular necrosis & 0 & $3.5 \pm 0.2^{\# \#}$ & $1.5 \pm 0.2^{* *}$ & $3.0 \pm 0.3$ & $2.3 \pm 0.2 * *$ & $1.7 \pm 0.2 * *$ \\
\hline
\end{tabular}

To quantify the histological indices for vacuolization and hepatocellular necrosis of liver, the slides were graded $0-4$ according to the method of Knodell et al. [16]. The liver damage was graded $0-4$ as following: $0=$ no visible cell damage; $1=$ slight $(1 \%-25 \%) ; 2=$ moderate $(26 \%-50 \%) ; 3=$ moderate/severe $(51 \%-75 \%) ; 4=$ severe/high $(76 \%-100 \%)$. * Significantly different from the control group $\left({ }^{\# \#} p<0.01\right)$; * Significantly different from the $\mathrm{CCl}_{4}$ group $\left({ }^{*} p<0.05, * * p<0.01\right)$; Values are mean $\pm \operatorname{SE}(n=6)$.

\subsection{Hepatic Lipid Peroxidation}

Lipid peroxidation plays a critical role in $\mathrm{CCl}_{4}$-induced liver injury [17]. To evaluate the effect of MOS $\mathrm{EtOH}$ pretreatment on $\mathrm{CCl}_{4}$-induced liver lipid peroxidation, malondialdehyde (MDA), the end product of lipid peroxidation, was monitored. It was found that administering $\mathrm{CCl}_{4}$ increased the hepatic level of MDA by about 1.3-fold compared to the control animals. This elevation was mitigated

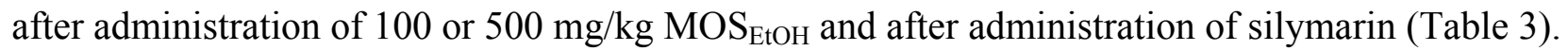

\subsection{Antioxidative Enzyme Activity of Liver}

Antioxidative enzyme activity in the liver was also analyzed. SOD activity in liver homogenates was decreased significantly after $\mathrm{CCl}_{4}$ administration (Table 3). SOD activity was increased significantly after pretreatment with either $100 \mathrm{mg} / \mathrm{kg}$ and $500 \mathrm{mg} / \mathrm{kg}$ of $\mathrm{MOS}_{\mathrm{EtOH}}$ and after pretreatment with silymarin. Both GPx and GR activity in $\mathrm{CCl}_{4}$-treated group liver homogenates were significantly lower than those of the normal group (Table 3). Furthermore, pretreatment with $\mathrm{MOS}_{\mathrm{EtOH}}$ increased the activities of both enzymes, as compared with the $\mathrm{CCl}_{4}$-treated group. 


\subsection{Hepatic NO Level Changes}

The nitrite level in the liver was significantly elevated in the $\mathrm{CCl}_{4}$ administered group of rats compared to the control rats (Table 3). Only a slight increase in hepatic nitrite levels was found compared to the control group when there was pretreatment with either $100 \mathrm{mg} / \mathrm{kg}$ or $500 \mathrm{mg} / \mathrm{kg}$ $\mathrm{MOS}_{\mathrm{EtOH}}$, and when there was pretreatment with silymarin; this indicates that the NO increase was attenuated by these pretreatments.

Table 3. Effect of $\mathrm{MOS}_{\mathrm{EtOH}}$ on the level of serum NO, hepatic MDA and antioxidative enzymes in rats treated with $\mathrm{CCl}_{4}$.

\begin{tabular}{|c|c|c|c|c|c|}
\hline \multirow{2}{*}{ Groups } & \multirow{2}{*}{$\begin{array}{c}\text { MDA } \\
\text { (nmoL/mg protein) }\end{array}$} & \multicolumn{3}{|c|}{ Activity (U/mg protein) } & \multirow{2}{*}{$\begin{array}{c}\text { NO } \\
(\mu \mathrm{M} / \mathrm{mg} \text { protein })\end{array}$} \\
\hline & & SOD & GPx & GRd & \\
\hline Control & $1.30 \pm 0.02$ & $19.26 \pm 0.61$ & $9.05 \pm 0.43$ & $0.193 \pm 0.006$ & $3.12 \pm 0.19$ \\
\hline $\mathrm{CCl}_{4}$ & $2.11 \pm 0.04^{\# \# \#}$ & $14.19 \pm 0.28^{\# \# \#}$ & $4.31 \pm 0.50$ & $0.145 \pm 0.001$ & $7.71 \pm 0.44^{\# \#}$ \\
\hline Silymarin $200 \mathrm{mg} / \mathrm{kg}+\mathrm{CCl}_{4}$ & $1.70 \pm 0.04 * * *$ & $18.99 \pm 0.43 * * *$ & $8.98 \pm 0.65 * * *$ & $0.169 \pm 0.002 * * *$ & $4.66 \pm 0.33 * * *$ \\
\hline $\mathrm{MOS}_{\mathrm{EtOH}} 20 \mathrm{mg} / \mathrm{kg}+\mathrm{CCl}_{4}$ & $1.99 \pm 0.06$ & $15.03 \pm 0.46$ & $5.60 \pm 0.51$ & $0.158 \pm 0.002$ & $6.49 \pm 0.33$ \\
\hline $\mathrm{MOS}_{\mathrm{EtOH}} 100 \mathrm{mg} / \mathrm{kg}+\mathrm{CCl}_{4}$ & $1.88 \pm 0.06 *$ & $16.78 \pm 0.42 * *$ & $6.89 \pm 0.16^{* *}$ & $0.164 \pm 0.003 * *$ & $5.53 \pm 0.40 * *$ \\
\hline $\mathrm{MOS}_{\mathrm{EtOH}} 500 \mathrm{mg} / \mathrm{kg}+\mathrm{CCl}_{4}$ & $1.81 \pm 0.05 * *$ & $18.23 \pm 0.43 * * *$ & $7.55 \pm 0.15 * * *$ & $0.171 \pm 0.003 * * *$ & $4.79 \pm 0.32 * * *$ \\
\hline
\end{tabular}

SOD: superoxide dismutase, GPx: glutathione peroxidase, GRd: glutathione reductase; MDA: malondialdehyde, NO: nitric oxide. \# Significantly different from the control group. $\left({ }^{\# \#} p<0.001\right)$; * Significantly different from the $\mathrm{CCl}_{4}$ group $(* p<0.05, * * p<0.01, * * * p<0.001)$; Values are mean $\pm \operatorname{SE}(n=6)$.

\section{Discussion}

Clinical medications are still unable to effectively control or treat liver disorders in humans. Patients suffering from liver diseases have started to try other methods of treatment, including complementary and alternative medicines (CAMs) to restore health; these treatments include herbal products [18,19]. Thus, numerous herbal medicines have been reported as being used for hepatoprotection. Mahonia oiwakensis Hayata, which is endemic plant in Taiwan, is a popular folk medicine that is traditionally used for treating inflammatory, gastrointestinal disorders and liver diseases in Taiwan. In this study, a single dose of $50 \% \mathrm{CCl}_{4}$ at $1 \mathrm{~mL} / \mathrm{kg}$ induced significant acute hepatic injury in rats, which was confirmed by the dramatic elevation in serum AST and ALT activity and the histological analysis. Additionally, $\mathrm{CCl}_{4}$ treatment also generated high MDA and NO levels and decreased SOD, GPx and GR levels; all of which are suggestive of oxidative stress. However, in this context, pretreatment with $\mathrm{MOS}_{\mathrm{EtOH}}$ had a significant hepatoprotection with respect to $\mathrm{CCl}_{4}$-induced acute liver injury in rats.

Cell membrane permeability is associated with cell death and increased enzyme activity, both of which contribute to hepatic structural damage [2]. Both ALT and AST are enzymes that are correlated with injury to hepatocytes. Previous studies have demonstrated that $\mathrm{CCl}_{4}$ increases AST and ALT levels in serum [1]. In this study, the serum ALT and AST levels were increased markedly at $24 \mathrm{~h}$ after $\mathrm{CCl}_{4}$ injection; furthermore, these increases were attenuated by treatment with $\mathrm{MOS}_{\mathrm{EtOH}}$ (100 and $500 \mathrm{mg} / \mathrm{kg}$ ). These experimental results suggest that $\mathrm{MOS}_{\mathrm{EtOH}}$ helps to maintain hepatocellular integrity and acts to prevent $\mathrm{CCl}_{4}$-induced hepatotoxicity; it does the above in a dose-dependent manner. The effect of $\mathrm{MOS}_{\mathrm{EtOH}}$ was similar to silymarin, which has been shown 
previously to have a significant protective effect in rats. The hepatoprotective effects were confirmed by histological examinations. $\mathrm{CCl}_{4}$ causes a range of histological changes to the liver, including vacuole formation, inflammation, cellular swelling and extended necrotic areas from the central area to the portal triads. Previous reports have shown that rats treated with $\mathrm{CCl}_{4}$ undergo increased neutrophil infiltration into the liver cells as liver injury progresses. Furthermore, it has also been found that reactive oxygen species (ROS), such as superoxide radicals $\left(\mathrm{O}_{2} \cdot\right)$, are released from these activated neutrophils that have infiltrated into the liver of the $\mathrm{CCl}_{4}$-treated rats, which causes extensive liver cell necrosis [2,3]. Again, silymarin is known to exhibit a protective effect in terms of these changes. In the present study, these changes were also significantly attenuated by $\mathrm{MOS}_{\mathrm{EtOH}}$ treatment.

Over-production of free radicals is toxic to hepatocytes and initiates ROS formation, which causes hepatocyte death and acute hepatic damage [20,21]. Based on this, antioxidative treatment has been proposed as a potential approach to preventing or attenuating toxic liver injury. Therefore, in this context, in vivo antioxidative activity was measured as part of this study by examining the activity levels of various antioxidative enzymes, namely SOD, GPx and GR. These antioxidative enzymes convert active oxygen molecules into non-toxic compounds and are easily inactivated by lipid peroxides or ROS during $\mathrm{CCl}_{4}$ exposure [2]. In this study, the experiment results showed that antioxidative enzyme activity levels in the $\mathrm{MOS}_{\mathrm{EtOH}}$ and silymarin groups were increased significantly compared with those of the group treated with $\mathrm{CCl}_{4}$ only. Therefore, both $\mathrm{MOS}_{\mathrm{EtOH}}$ and silymarin exert a protective effect against $\mathrm{CCl}_{4}$-induced hepatic injury and this is, at least in part, via their effect on hepatic antioxidative activity, which is able to reduce ROS production. The free radical, NO, is a highly reactive nitrogen species produced by parenchymal and nonparenchymal liver cells from L-arginine via nitric oxide synthase activity [22]. Thus, NO may contribute to the cytotoxic effect of neutrophils by forming peroxinitrite after it reacts with various ROS, particularly $\mathrm{O}_{2}$ [23,24]. In this study, only a slight increase in hepatic NO levels was noted in rats pretreated with $\mathrm{MOS}_{\mathrm{EtOH}}$ or silymarin compared to rats administered with $\mathrm{CCl}_{4}$ alone, which showed a large increase. Suppression of NO production is likely due to the increases in SOD, GPx and GR activity induced by pretreatments.

Lipid peroxidation has been hypothesized to be a principal cause of $\mathrm{CCl}_{4}$-induced liver injury and can therefore be used as a marker of oxidative damage. The scavenging of free radicals is one of the major antioxidative mechanisms able to inhibit the chain reaction of lipid peroxidation. DPPH is known to abstract labile hydrogen [25]. The scavenging of DPPH radicals is thus related to the inhibition of lipid peroxidation [26]. The experiment results for DPPH scavenging activity suggests that $\mathrm{MOS}_{\mathrm{EtOH}}$ is able to exert a free radical scavenging effect that could have a beneficial action against pathological alterations caused by free radicals generated by $\mathrm{CCl}_{3}$ and by lipid peroxidation. The final product of lipid peroxidation, MDA, is widely used as a marker of lipid peroxidation [27]. The fact that near-normal levels of hepatic MDA are maintained after $\mathrm{MOS}_{\mathrm{EtOH}}$ pretreatment provides additional evidence indicating that $\mathrm{MOS}_{\mathrm{EtOH}}$ has hepatoprotective activity. The results of the present study indicate that $\mathrm{MOS}_{\mathrm{EtOH}}$ has antioxidative capacity, protects hepatocytes from oxidative stress, inhibits lipid peroxidation, reduces NO production, and enhances antioxidative activity in the rat livers that have been treated with $\mathrm{CCl}_{4}$.

Identification of the major compounds in a herb or a herbal preparation should prove helpful when elucidating pharmacological activity and the underlying mechanisms of action [8]. Protoberberine alkaloids are the predominant components of Berberis, Mahonia and Coptis, which have long histories 
as folk medicines [13]. The major compounds in $\mathrm{MOS}_{\mathrm{EtOH}}$ were analyzed by HPLC. A number of major peaks were identified and these were found to be berberine, palmatine, and jatrorrhizine (Figure 1). Previous studies have demonstrated that berberine, palmatine, and jatrorrhizine possess significant anti-inflammatory and hepatoprotective activities [25,26]. Berberine, which is also present in Coptidis rhizoma and Phellodendri cortex, is known to scavenge $\mathrm{O}_{2} \cdot$ in vitro [28]. In this study, the analytical data indicates that the protoberberine alkaloids of berberine, palmatine, and jatrorrhizine make up $30 \%$ of the ingredients of $\mathrm{MOS}_{\mathrm{EtOH}}$. Thus, the hepatoprotective activity of $\mathrm{MOS}_{\mathrm{EtOH}}$ may relate to the presence of these alkaloids in $\mathrm{MOS}_{\mathrm{EtOH}}$. Further in-depth studies are necessary in order to explore the mechanisms of action of $\mathrm{MOS}_{\mathrm{EtOH}}$ and its individual components.

In nature, there are a great deal of natural plants with anti-inflammatory properties; flavonoids provide one of the more famous examples of a powerful ingredient found among these plants [29]. Flavonoids are polyphenolic compounds that are ubiquitous in nature and are categorized, according to chemical structure, into flavonols, flavones, flavanones, isoflavones, catechins, anthocyanidins and chalcones [30]. Over 4000 flavonoids have been identified, many of which occur in fruits (grape), vegetables (onions) and beverages (tea, wine and fruit drinks) [31,32]. Antioxidants are compounds that protect cells against the damaging effects of reactive oxygen species, such as singlet oxygen, superoxide, peroxyl radicals, hydroxyl radicals and peroxynitrite. An imbalance between antioxidants and reactive oxygen species results in oxidative stress, leading to cellular damage. Oxidative stress has been linked to cancer, aging, atherosclerosis, ischemic injury, inflammation and neurodegenerative diseases. The antioxidant activity of flavonoids depends on their molecular structure, and structural characteristics of certain flavonoids found in hops and beer confer surprisingly potent antioxidant activity exceeding that of red wine, tea, or soy.

Vegetables contain many physiologically active substances, and they can manipulate the growth of the plants and provide some pigments for the plants. These elements are called phytochemicals. Recently, epidemiological research indicated that fruits and vegetables in meals can reduce the risk of degenerative disease. This is the result of foods that might include plant phytochemicals. In the past, the related research of flavonoids was not valued. People usually get a small amount of flavonoids from the fruits and vegetables or in tea and alcoholic drinks [33], thus they have only paid attention to the ingredients in vegetables that offer some fructose and fibers, eschewing deeper investigation into the flavonoids' metabolism, its decomposition, and its physiological effects after it has been metabolized. This area will be the focus of our future research.

\section{Experimental Section}

\subsection{Chemicals}

Berberine, palmatine, silymarin, Griess reagent and other chemicals were purchased from Sigma-Aldorich Chemical Co (St. Louis, MO, USA). Jatrorrhizine was purchased from the National Institute for the Control of Pharmaceutical and Biological Products (Beijing, China). $\mathrm{CCl}_{4}$ was purchased from Merck Co. (Merck KGaA, Darmstadt, Germany). The SOD, GPx and GR assay kits were purchased from Randox Laboratory Ltd. (London, UK). $\mathrm{CCl}_{4}$ was dissolved in olive oil as $50 \%$ 
$(v / v)$ solution. Silymarin was suspended in $2 \%$ carboxymethyl cellulose. All other chemicals or reagents used were of analytical grade or HPLC grade.

\subsection{Plant Source and Preparation of Plant Extract}

The MO was collected from the Alishan mountainous area of Taiwan, and was identified by Chao-Lin Kuo, leader of the School of Chinese Medicine Resources (SCMR); a voucher specimen (Number: CMU MO 0722) was deposited at the SCMR. The crude MOS were sliced into small pieces, which were then dried in a circulating air stove and grounded up (453.4 g). Ten liters of ethanol were added to the dried powder. The MOS was extracted using $95 \%$ ethanol for $48 \mathrm{~h}$ four consecutive times. The filtrates were combined and concentrated under reduced pressure at $40{ }^{\circ} \mathrm{C}$ using a vacuum rotary evaporator in order to obtain $\mathrm{MOS}_{\mathrm{EtOH}}$ extract. The yield ratio of the $\mathrm{MOS}_{\mathrm{EtOH}}$ lyophilized extract (12.55 g) was $2.7 \%$.

\subsection{Chromatographic Identification of $M O S_{E t O H}$}

The HPLC system consisted of a Shimadzu (Kyoto, Japan) LC-10ATvp liquid chromatograph equipped with a DGU-14A degasser, an FCV-10ALvp low-pressure gradient flow control valve, a SIL-10ADvp auto injector, an SPD-M10Avp diode array detector, and an SCL-10Avp system controller. Peak areas were calculated using Shimadzu Class-LC10 software (Version 6.12 sp5). The column was a Phenomenex Synergi 4 Fusion-RP 80A column $(250 \times 4.6 \mathrm{~mm})$. The gradient mobile phase was methanol (solvent $\mathrm{A}$ ) and $1 \%$ triethylamine plus $1 \%$ acetic acid in water adjusted to $\mathrm{pH} 3.0$ using phosphoric acid (solvent B). The sample was injected of $10 \mu \mathrm{L}$. The gradient profile was run at $1 \mathrm{~mL} \mathrm{~min}{ }^{-1}$ over $100 \mathrm{~min}$. The gradient program was as follow: 10-12 $\mathrm{min} 26 \% \mathrm{~B}$ isocratic, $12-14 \min 26 \%-28 \% \mathrm{~B}, 14-19 \min 28 \% \mathrm{~B}$ isocratic, $19-20 \min 28 \%-34 \%, 20-38 \min 34 \% \mathrm{~B}$ isocratic, 38-39 min 34\%-42\% B, 39-49 min 42\% B isocratic, 49-50 min 42\%-48\% B, 50-59 min $48 \% \mathrm{~B}$ isocratic, $59-60 \min 48 \%-55 \% \mathrm{~B}, 60-71 \min 55 \%-70 \% \mathrm{~B}, 71-80 \min 70 \% \mathrm{~B}$ isocratic, $80-100 \min 70 \%-26 \% \mathrm{~B}$. The solvent (mobile phase) was allowed to run for 3-5 min as the initial phase before injecting the next sample.

The peaks found in the $\mathrm{MOS}_{\mathrm{EtOH}}$ samples were identified by comparison with the standard solutions of berberine, palmatine, and jatrorrhizine. The $\mathrm{MOS}_{\mathrm{EtOH}}$ solutions were quantified by spiking with a known amount of standard and comparing the areas under the curve. The repeatability of the method was evaluated by injecting $\mathrm{MOS}_{\mathrm{EtOH}}$ and the standard solutions three times, and the relative standard deviation (RSD) percentage was then calculated.

\subsection{Determination of DPPH Radical Scavenging Ability}

The effect of crude extracts and the positive controls (Vit. C, ascorbic acid; BHT, 2,6-Di-tert-butyl-4-methylphenol) on the DPPH radical scavenging ability was estimated according to a previously described method [34]. An aliquot $(20 \mu \mathrm{L})$ of crude extracts at various concentrations was mixed with $100 \mathrm{mM}$ Tris-HCl buffer $(80 \mu \mathrm{L}, \mathrm{pH} 7.4)$ and then with $100 \mu \mathrm{L}$ of the DPPH in ethanol to a final concentration of $250 \mu \mathrm{M}$. The mixture was shaken vigorously and left to stand at room temperature for $20 \mathrm{~min}$ in the dark. The absorbance at $517 \mathrm{~nm}$ of the reaction solution was measured 
spectrophotometrically. The percentage of DPPH decolorization of the samples was calculated according to the equation: $\%$ decolorization $=[1-($ ABS sample/ABS control $)] \times 100$. The half inhibitory concentration $\left(\mathrm{IC}_{50}\right)$ value was the effective concentration at which DPPH radicals were scavenged by $50 \%$ and was obtained by interpolation from a linear regression analysis. A lower $\mathrm{IC}_{50}$ value indicates a greater antioxidative activity.

\subsection{Animals}

Male ICR mice (18 22 g) and Male Wistar rats (250 300 g) were obtained from the Animal Center of National Taiwan University (Taipei, Taiwan). They were housed in standard cages at a constant temperature of $22{ }^{\circ} \mathrm{C} \pm 1{ }^{\circ} \mathrm{C}$, relative humidity $55 \% \pm 5 \%$ with $12 \mathrm{~h}$ light-dark cycle (08:00 to 20:00) for at least 1 week before experimentation began.

Animals used in this study were housed and cared for in accordance with the NIH Guide for the Care and Use of Laboratory Animals. The experimental protocol was approved by the Committee on Animal Research, China Medical University, under the code 2006-14-N. All tests were conducted under the guidelines of the International Association for the Study of Pain.

\subsection{Acetic Acid-Induced Writhing Test}

The writhing test in mice was conducted as described in the previous study [35]. Male ICR mice (ten per group) were fasted for $24 \mathrm{~h}$ before the experiment, but with free access to water. The writhes were induced by an intraperitoneal injection of $1.0 \%$ acetic acid in distilled water $(0.1 \mathrm{~mL} / 10 \mathrm{~g}$ body weight). Preliminary data showed that a dosage of $1.0 \mathrm{~g} / \mathrm{kg}$ possesses maximum anti-inflammatory effects, and based on this, we chose three doses for subsequent animal experiments. Mice were administered orally with $\operatorname{MOS}_{\mathrm{EtOH}}(20,100$ and $500 \mathrm{mg} / \mathrm{kg}) 60 \mathrm{~min}$ prior to chemical induction of writhes and the same volume of distilled water by oral administration as the vehicle control. Indomethacin $(10 \mathrm{mg} / \mathrm{kg}$, i.p) was administered $30 \mathrm{~min}$ prior to acetic acid injection. Mice were placed in an observation box separately and the number of writhing responses was counted over $10 \mathrm{~min}$.

\subsection{Formalin Test}

The test was conducted according to the method described in the previous study [36]. Male ICR mice (ten per group) were fasted for $24 \mathrm{~h}$ before the experiment, but with free access to water. Twenty microliters of $5 \%$ formalin in distilled water was then injected subcutaneously into the right hind paw of mice to cause pain. Mice were administered orally with $\operatorname{MOS}_{\mathrm{EtOH}}(20,100$ and $500 \mathrm{mg} / \mathrm{kg}) 60 \mathrm{~min}$ before formalin treatment and the same volume of distilled water by oral administration as the vehicle control. Indomethacin (10 mg/kg, i.p) was administered $30 \mathrm{~min}$ before formalin treatment. These mice were individually placed in a transparent Plexiglas cage $(25 \times 15 \times 15 \mathrm{~cm})$. The time spent licking and biting the injected paw was used as the index of pain and was recorded separately from 0 to 5 min as early phase or neurogenic pain and from 20 to $30 \mathrm{~min}$ as late phase or inflammatory pain [37]. 


\subsection{Carrageenan-Induced Mice Paw Edema}

This method was carried out previously described but with some modifications [38]. Male ICR mice $(N=10)$ were fasted for $24 \mathrm{~h}$ before the experiment with free access to water. The mice were injected subcutaneously with $50 \mu \mathrm{L}$ of $1 \%$ carrageenan solution in normal saline $(0.9 \% \mathrm{w} / v \mathrm{NaCl})$ into the sub-plantar region of the right hind paw. Paw volume was measured using a plethysmometer immediately before injection and 1, 2, 3, and $4 \mathrm{~h}$ after the administration of the carrageenan. $\mathrm{MOS}_{\mathrm{EtOH}}$ $(20,100$ and $500 \mathrm{mg} / \mathrm{kg}$ ) was administered at $120 \mathrm{~min}$ after carrageenan injection. Indomethacin $(10 \mathrm{mg} / \mathrm{kg}$, i.p), a therapeutic control, was administered at $150 \mathrm{~min}$ after carrageenan injection. The percent increase in paw volume was calculated and compared with the vehicle control.

\subsection{Hepatoprotective Effect}

For the dose selection of $\mathrm{MOS}_{\mathrm{EtOH}}$, the acute oral toxicity of $\mathrm{MOS}_{\mathrm{EtOH}}$ in rats was single gavaged at three levels of 500, 2500, and $5000 \mathrm{mg} / \mathrm{kg}$ body weight at a volume of $10 \mathrm{~mL} / \mathrm{kg}$. The results were observed for $48 \mathrm{~h}$. Results revealed that $\mathrm{MOS}_{\mathrm{EtOH}}$, up to $5000 \mathrm{mg} / \mathrm{kg}$ body weight, did not cause any significant behavioral changes and no mortality occurred. For the liver protection experiments, control and $\mathrm{CCl}_{4}$-treated rats were orally administered, and distilled water was used as the non-therapeutic control. The therapeutic control group weas given silymarin $(200 \mathrm{mg} / \mathrm{kg})$ orally for three consecutive days. The $\mathrm{MOS}_{\mathrm{EtOH}}$ group of rats were orally administered $\mathrm{MOS}_{\mathrm{EtOH}}(20,100$ and $500 \mathrm{mg} / \mathrm{kg})$ for three consecutive days. One hour after the last administration of the experimental drugs, $\mathrm{CCl}_{4}(1 \mathrm{~mL} / \mathrm{kg}$, $50 \% \mathrm{v} / \mathrm{v}$ ) was injected intraperitoneally into each group of rats, except for the control group. Control rats received a comparable volume of olive oil (i.p). Twenty-four hours after $\mathrm{CCl}_{4}$ injection, the rats were sacrificed under anesthesia and blood was collected for evaluation of the biochemical parameters (AST and ALT levels). Liver tissue was removed for histological evaluation, and parts of livers were also collected to allow the SOD, GPx and GRd, MDA and NO contents to be measured.

\subsection{Histopathological Evaluation}

All animals were subjected to necropsy at the end of experiment. The livers were observed grossly and then excised, blotted and weighed. The weights of liver are represented as percentage of final body weight. Tissues were fixed in $10 \%$ buffered formaldehyde solution and embedded in paraffin. The specimens were cut into $2 \mu \mathrm{m}$ sections, stained with hematoxylin and eosin, and then examined by light microscopy.

\subsection{Antioxidative Enzyme Activity Measurements}

SOD enzyme activity was determined according to a previously described method at room temperature [36]. Tissue extract $(100 \mu \mathrm{L})$ was added to $880 \mu \mathrm{L}(0.05 \mathrm{M}, \mathrm{pH} 10.2,0.1 \mathrm{mM}$ EDTA) carbonate buffer. Epinephrine, $30 \mathrm{mM}$ in $0.05 \%$ acetic acid $(20 \mu \mathrm{L})$ was added to the mixture and the absorbance at $480 \mathrm{~nm}$ for 4 min was measured on a Hitachi U 2000 spectrophotometer. The enzyme activity is represented as the amount of enzyme that inhibits the oxidation of epinephrine by $50 \%$, which is equal to 1 unit, and is expressed as $\mathrm{U} / \mathrm{mg}$ protein. 
The GPx enzyme activity was determined according to the method of Flohe and Gunzler [37] at $37{ }^{\circ} \mathrm{C}$. A reaction mixture consisted of $500 \mu \mathrm{L}$ phosphate buffer, $100 \mu \mathrm{L} 0.01 \mathrm{M}$ GR (reduced form), $100 \mu \mathrm{L} 1.5 \mathrm{mM}$ NADPH and $100 \mu \mathrm{L}$ GR $(0.24$ units). Ttissue extract $(100 \mu \mathrm{L})$ was added to the reaction mixture and incubated at $37^{\circ} \mathrm{C}$ for $10 \mathrm{~min}$. Then $50 \mu \mathrm{L}$ of $12 \mathrm{mM} t$-butyl hydroperoxide was added to $450 \mu \mathrm{L}$ of the tissue reaction mixture and the absorbance measured at $340 \mathrm{~nm}$ for $180 \mathrm{~s}$. The molar extinction coefficient of $6.22 \times 10^{-3}$ was used to determine the enzyme activity. One unit of activity is equal to the $\mathrm{mM}$ of NADPH oxidized $\mathrm{min}^{-1}$ per $\mathrm{mg}$ protein. NADPH $(2 \mathrm{mM}, 50 \mu \mathrm{L})$ in $10 \mathrm{mM}$ Tris buffer ( $\mathrm{pH} 7.0$ ) was added to a cuvette containing $50 \mu \mathrm{L}$ of GSSG (20 mM) in phosphate buffer. Tissue extract $(100 \mu \mathrm{L})$ was added to the NADPH-GSSG buffered solution and the absorbance measured at $340 \mathrm{~nm}$ for $3 \mathrm{~min}$. The molar extinction coefficient of $6.22 \times 10^{-3}$ was used to determine GR enzyme activity. One unit of activity is equal to the $\mathrm{mM}$ of NADPH oxidized $\mathrm{min}^{-1}$ per $\mathrm{mg}$ protein and expressed as $\mathrm{U} / \mathrm{mg}$ protein.

\subsection{Hepatic MDA and NO Assay}

The MDA levels in the liver tissue samples were evaluated by the thiobarbituric acid reacting substance (TRARS) method [39]. Briefly, MDA reacts with thiobarbituric acid at an acidic high temperature and forms a red-complex TBARS. The absorbance of TBARS was determined at $532 \mathrm{~nm}$ (Hitachi U 2000, Tokyo, Japan) and expressed as nmoL/mg protein.

Hepatic NO was measured according to the method of Moshage et al. [40]. For the nitrite determination, $\mathrm{NO}_{3}{ }^{-}$was converted into nitrite by nitrate reductase enzymatic conversion; $\mathrm{NO}_{2}{ }^{-}$was measured by the Griess reaction [41]. Values obtained by this procedure represent the sum of nitrite and nitrate (Hitachi U 2000, Tokyo, Japan) and expressed as $\mu \mathrm{M} / \mathrm{mg}$ protein.

\subsection{Statistical Analysis}

All the data are shown as mean \pm SE. The data in the present study were analyzed by one-way ANOVA followed by Bonferroni post hoc test. The exception was the liver histoscores, which were analyzed using nonparametric statistics. The criterion for statistical significance were ${ }^{\#} p<0.05$, ${ }^{\#} p<0.01$ and ${ }^{\# \#} p<0.001$ for the comparison between $\mathrm{CCl}_{4}$ and the control groups, and $* p<0.05$, $* * p<0.01$ and $* * * p<0.001$ for the comparison between the $\mathrm{MOS}_{\mathrm{EtOH}}$ and $\mathrm{CCl}_{4}$ groups.

\section{Conclusions}

This study demonstrates that $\mathrm{MOS}_{\mathrm{EtOH}}$ exhibits antioxidant, analgesic, anti-inflammatory, and hepatoprotective effects. The anti-inflammatory and hepatoprotective effects of $\mathrm{MOS}_{\mathrm{EtOH}}$ seem to be related to a modulation of antioxidant enzyme activity in the liver together with decreases in the malondialdehyde (MDA) level of the liver and nitric oxide (NO) content of the liver. The hepatoprotective mechanisms of $\mathrm{MOS}_{\mathrm{EtOH}}$ when orally administered are via a preventive effect on liver injury progression in $\mathrm{CCl}_{4}$-treated rats; this seems to involve the maintaining of the liver antioxidative defense systems in addition to the scavenging of ROS and NO; these lead to an inhibition of lipid peroxidation. Thus it would seem that $\mathrm{MOS}_{\mathrm{EtOH}}$ acts as a pharmacological agent that is able to prevent inflammatory and liver disorders. 


\section{Acknowledgements}

This study was supported by grants from the China Medical University (CMU96-168, CMU97-085, and CMU97-142). We would like to express my thanks to Ted Knoy for revising the English language in this manuscript.

\section{References}

1. Lee, C.P.P.; Shih, H.; Hsu, C.L.; Yen, G.C. Hepatoprotection of tea seed oil (Camellia oleifera Abel.) against $\mathrm{CCl}_{4}$-induced oxidative damage in rats. Food Chem. Toxicol. 2007, 6, 888-895.

2. Recknagel, R.O.; Glende, E.A.; Dolak, J.A.; Waller, R.L. Mechanisms of carbon tetrachloride toxicity. Pharmacol. Ther. 1989, 1, 139-154.

3. Weber, L.W.; Boll, M.; Stampfl, A. Hepatotoxicity and mechanism of action of haloalkanes: Carbon tetrachloride as a toxicological model. Crit. Rev. Toxicol. 2003, 2, 105-136.

4. Forni, L.G.; Packer, J.E.; Slater, T.F.; Willson, R.L. Reaction of the trichloromethyl and halothane-derived peroxy radicals with unsaturated fatty acids: A pulse radiolysis study. Chem. Biol. Interact. 1983, 2, 171-177.

5. McCay, P.B.; Lai, E.K.; Poyer, J.L.; DuBose, C.M.; Janzen, E.G. Oxygen- and carbon-centered free radical formation during carbon tetrachloride metabolism. Observation of lipid radicals in vivo and in vitro. J. Biol. Chem. 1984, 4, 2135-2143.

6. Gancevici, G.G. Bioeffects of the plant Mahonia sempervirens. Arch. Roum. Pathol. Exp. Microbiol. 1990, 2, 183-190.

7. Rohrer, U.; Kunz, E.M.; Lenkeit, K.; Schaffner, W.; Meyer, J. Antimicrobial activity of Mahonia aquifolium and two of its alkaloids against oral bacteria. Schweiz. Monatsschr. Zahnmed. 2007, 11, 1126-1131.

8. Tseng, S.H.; Chien, T.Y.; Tzeng, C.F.; Lin, Y.H.; Wu, C.H.; Wang, C.C. Prevention of hepatic oxidative injury by Xiao-Chen-Chi-Tang in mice. J. Ethnopharmacol. 2007, 2, 232-239.

9. Kan, W.S. Pharmaceutical Botany; National Research Institute of Chinese Medicine: Taipei, Taiwan, 1993.

10. Chao, J.; Lu, T.C.; Liao, J.W.; Huang, T.H.; Lee, M.S.; Cheng, H.Y.; Ho, L.K.; Kuo, C.L.; Peng, W.H. Analgesic and anti-inflammatory activities of ethanol root extract of Mahonia oiwakensis in mice. J. Ethnopharmacol. 2009, 2, 297-303.

11. Wong, B.S.; Hsiao, Y.C.; Lin, T.W.; Chen, K.S.; Chen, P.N.; Kuo, W.H.; Chu, S.C.; Hsieh, Y.S. The in vitro and in vivo apoptotic effects of Mahonia oiwakensis on human lung cancer cells. Chem. Biol. Interact. 2009, 2, 165-174.

12. Kan, W.S. Manual of Medicinal Plants in Taiwan (I); National Research Institute of Chinese Medicine: Taipei, Taiwan, 1980.

13. Luo, Y.C.; Yeh, L.F.; Zhang, K.C.; Lu, F.Y. Ethnobotany in North Tsou tribe. Nat. Conserv. Q. 2007, 58, 27-31.

14. Rackova, L.; Majekova, M.; Kost'alova, D.; Stefek, M. Antiradical and antioxidant activities of alkaloids isolated from Mahonia aquifolium structural aspects. Bioorg. Med. Chem. 2004, 12, 4709-4715. 
15. Moshage, H.; Kok, B.; Huizenga, J.R.; Jansen, P.L. Nitrite and nitrate determinations in plasma: A critical evaluation. Clin. Chem. 1995, 41, 892-896.

16. Knodell, R.G.; Ishak, K.G.; Black, W.C.; Chen, T.S.; Craig, R.; Kaplowitz, N.; Kiernan, T.W.; Wollman, J. Formulation and application of a numerical scoring system for assessing histological activity in asymptomatic chronic active hepatitis. Hepatology 1981, 1, 431-435.

17. Green, L.C.; Wagner, D.A.; Glogowski, J.; Skipper, P.L.; Wishnok, J.S.; Tannenbaum, S.R. Analysis of nitrate, nitrite, and [15N] nitrate in biological fluids. Anal. Biochem. 1982, 126, 131-138.

18. Basu, S. Carbon tetrachloride-induced lipid peroxidation: Eicosanoid formation and their regulation by antioxidant nutrients. Toxicology 2003, 189, 113-127.

19. Seeff, L.B.; Lindsay, K.L.; Bacon, B.R.; Kresina, T.F.; Hoofnagle, J.H. Complementary and alternative medicine in chronic liver disease. Hepatology 2001, 34, 595-603.

20. Strader, D.B.; Bacon, B.R.; Lindsay, K.L.; La Brecque, D.R.; Morgan, T.; Wright, E.C.; Allen, J.; Khokar, M.F.; Hoofnagle, J.H.; Seeff, L.B. Use of complementary and alternative medicine in patients with liver disease. Am. J. Gastroenterol. 2002, 97, 2391-2397.

21. Bissell, D.M.; Gores, G.J.; Laskina, D.L.; Hoofnagle, J.H. Drug-induced liver injury: Mechanisms and test systems. Hepatology 2001, 33, 1009-1013.

22. Aeschke, H.; Gores, G.J.; Cederbaum, A.I.; Hinson, J.A.; Pessayre, D.; Lemasters, J.J. Mechanisms of hepatotoxicity. Toxicol. Sci. 2002, 65, 166-176.

23. Eller, D.A.; de Vera, M.E.; Russell, D.A.; Shapiro, R.A.; Nussler, A.K.; Simmons, R.L.; Billiar, T.R. A central role for IL-1 $\beta$ in the in vitro and in vivo regulation of hepatic inducible nitric oxide synthase. IL-1 $\beta$ induces hepatic nitric oxide synthesis. J. Immunol. 1995, 155, 4890-4898.

24. Rodenas, J.; Mitjavila, M.T.; Carbonell, T. Simultaneous generation of nitric oxide and superoxide by inflammatory cells in rats. Free Radic. Biol. Med. 1995, 18, 869-875.

25. Smith, J.A. Neutrophils, host defense, and inflammation: A double-edged sword. J. Leukoc. Biol. 1994, 56, 672-686.

26. Matsubara, N.; Fuchimoto, S.; Iwagaki, H.; Nonaka, Y.; Kimura, T.; Kashino, H.; Edamatsu, R.; Hiramatsu, M.; Orita, K. The possible involvement of free radical scavenging properties in the actions of cytokines. Res. Commun. Chem. Pathol. Pharmacol. 1991, 71, 239-242.

27. Ratty, A.K.; Sunamoto, J.; Das, N.P. Interaction of flavonoids with 1,1-diphenyl-2-picrylhydrazyl free radical, liposomal membranes and soybean lipoxygenase-1. Biochem. Pharmacol. 1988, 37, 989-995.

28. Ohkawa, H.; Ohishi, N.; Yagi, K. Assay for lipid peroxides in animal tissues by thiobarbituric acid reaction. Anal. Biochem. 1979, 95, 351-358.

29. Rodrigues, A.S.; Perez-Gregorio, M.R.; Garcia-Falcon, M.S.; Simal-Gandara, J.; Almeida, D.P.F. Effect of meteorological conditions on antioxidant flavonoids in Portuguese cultivars of white and red onions. Food Chem. 2011, 124, 303-308.

30. Rodrigues, A.S.; Perez-Gregorio, M.R.; Garcia-Falcon, M.S.; Simal-Gandara, J. Effect of curing and cooking on flavonols and anthocyanins in traditional varieties of onion bulbs. Food Res. Int. 2009, 42, 1331-1336. 
31. Perez-Gregorio, M.R.; Regueiro, J.; Gonzalez-Barreiro, C.; Rial-Otero, R.; Simal-Gandara, J. Changes in antioxidant flavonoids during freeze-drying of red onions and subsequent storage. Food Control 2011, 22, 1108-1113.

32. Perez-Lammela, C.; Garcia-Falcon, M.S.; Simal-Gandara, J.; Orriols-Fernandez, I. Influence of grape variety, vine system and enological treatments on the colour stability of young red wines. Food Chem. 2007, 101, 601-606.

33. Alonso Garcia, A.; Cancho Grande, B.; Simal-Gandara, J. Development of a rapid method based on solid-phase extraction and liquid chromatography with ultraviolet detection for the determination of polyphenols in alcohol-free beers. J. Chromatogr. A 2004, 1054, 175-180.

34. Yamaguchi, T.; Takamura, H.; Matoba, T.; Terao, J. HPLC method for evaluation of the free radical-scavenging activity of foods by using 1,1-diphenyl-2-picrylhydrazyl. Biosci. Biotechnol. Biochem. 1998, 62, 1201-1204.

35. Chiu, Y.J.; Huang, T.H.; Chiu, S.H.; Lu, T.C.; Chen, T.W.; Peng, W.H.; Chen, C.Y. Analgesic and anti-inflammatory activities of the extract from Plectranthus amboinicus (Lour.) spreng. both in vitro and in vivo animal models. Evid. Based Complement. Alternat. Med. 2012, 2012, 1-11.

36. Mitchell, J.R.; Jollow, D.J.; Potter, W.Z.; Gillette, J.R.; Brodie, B.B. Acetaminophen-induced hepatic necrosis. IV. Protective role of glutathione. J. Pharmacol. Exp. Ther. 1973, 187, 211-217.

37. Hunskaar, S.O.; Berge, G.; Hole, K. Antinociceptive effects of orphenadrine citrate in mice. J. Ethnopharmacol. 1985, 111, 221-226.

38. Zimmermann, M. Ethical guidelines for investigations of experimental pain in conscious animals. Pain 1983, 16, 109-110.

39. Lu, T.C.; Ko, Y.Z.; Huang, H.W.; Huang, Y.C.; Lin, Y.C.; Peng, W.H. Analgesic and anti-inflammatory activities of aqueous extract from Glycine tomentella root in mice. J. Ethnopharmacol. 2007, 113, 142-148.

40. Flohe, L.; Gunzler, W.A. Assays of glutathione peroxidase. Methods Enzymol. 1984, 105, 114-121.

41. Carlberg, I.; Mannervik, B. Glutathione reductase. Methods Enzymol. 1985, 113, 484-490.

(C) 2013 by the authors; licensee MDPI, Basel, Switzerland. This article is an open access article distributed under the terms and conditions of the Creative Commons Attribution license (http://creativecommons.org/licenses/by/3.0/). 